\title{
Deep Integration of Innovation-Entrepreneurship Education and Professional Education
}

\author{
Jianhu Zheng ${ }^{1, \mathrm{a}}$, Hui Chen ${ }^{1, \mathrm{~b}}$ and Mingfang Huang ${ }^{1, \mathrm{c}, *}$
}

\author{
${ }^{I}$ Department of Economics and Management, Minjiang University, Fuzhou, Fujian, China \\ ajianhu1028@163.com, ${ }^{b} 55826882 @ q q . c o m,{ }^{c} 83553948 @ q q . c o m$ \\ *Corresponding author
}

\begin{abstract}
Reform of innovation-entrepreneurship education is an important way to improve the quality of higher education. Taking Logistics Engineering of Minjiang University as example, how to solve the integration of innovation-entrepreneurship education and professional education are discussed. Firstly, the management institute should be built and the corresponding rules should be formulated, which is key component of the top-level design of university. Secondly, construction of curriculum system is critical for education reform, which contain innovation-entrepreneurship education idea, practice teaching and second course. Finally, the mechanism of implementation and guarantee is analyzed. The integration of innovation-entrepreneurship education and professional education is important throughout four years of study.
\end{abstract}

Keywords: innovation-entrepreneurship, professional education, integration path

\section{创新创业教育与专业教育的深度融合路径研究}

郑建湖 ${ }^{1, a}$, 陈慧 $1, \mathrm{~b}$, 黄明芳 $1, \mathrm{c}, *$

\author{
1 经济与管理学院, 阑江学院, 福州, 福建省, 中国 \\ ${ }^{a}$ zjianhu1028@163.com, ${ }^{b} 55826882 @ q q . c o m,{ }^{c} 83553948 @ q q . c o m$ \\ *通讯作者
}

\section{摘要}

高校创新创业教育改革是提高人才培养质量的重要举措。以闽江学院物流工程专业为例, 对创新创业 教育如何与专业相融合的问题进行探讨。首先, 从学校顶层设计方面, 应建立相应的组织管理机构和 制定相关政策措施; 其次从课程体系建设方面, 对创新创业教育理念融入课程体系、实践教学和第二 课程进行了阐述; 最后对创新创业教育的实施和保障机制进行了探讨。提出了创新创业教育与专业教 育的融合路径，构建创新创业教育融入专业人才培养的全过程，为高校深化教育改革提供保障。

关键词：创新创业教育，专业教育，融合路径

\section{1. 引言}

我国国民经济发展速度从高速增长转为中低速增长, 经济 发展也从投资和要素驱动转为创新驱动发展。高等教育为 了顺应经济社会发展的这一转变, 提出了一系列深化高等 教育改革的主要内容, 其中 “双创教育” 是深化高等教育 教学改革最为重要的内容之一 $[1]$ 。大众创业、万众创新 是实施国家 “创新驱动发展” 战略的重要载体, 国务院于 2015 年和 2017 年先后发布了《关于深化高等学校创新创 业教育改革的实施意见》和《国家教育事业发展“十三五” 规划》两份文件, 以及随后印发的一系列关于创新创业教 育改革的政策文件, 明确提出高校应加强创新创业教育改 革, 着力培养学生的创新能力和创业精神。

高等教育与经济社会发展相协调, 注重学生知识与能力、 技术与技能的全面发展, 尤其重视学生创新思维和创业精 神的培养, 是目前高等教育深化创新创业教育改革的共同 目标。然而, 我国创新创业教育起步较晚, 与许多发达国
家相比，创新创业教育还未形成完整的人才培养体系，各 个高校对创新创业教育的认识也未形成一致的认识, 创新 创业教育还处在探索和深化的阶段。创新创业教育与专业 教育还未实现真正意义上的融合, 许多高校的创新创业教 育还是相对独立的培养体系, 与各个专业的结合还比较薄 弱。

由于对双创教育理念的认知不足, 普遍存在 “双创教育” 与专业教育相脱节的现象, 主要体现在以下几个方面 [2-4]: 1）缺乏强有力的人才培养目标导向。对于学生方面, 传 统的考核制度和考核方法依然是评判学生的单一手段; 对 于教师方面，双创教育还没有纳入教师的业绩考核，通常 还没有与教师岗位聘任、职称晋升等挂钩。2）“双创教 育”未与专业教育有机融合。虽然 “双创型”人才培养的 各种政策、制度不断出台, 增设了创新创业类课程, 对于 传统教育模式是一个有意的补充, 但专业人才培养模式任 没有得到根本性转变。3）缺乏合格的 “双创型” 师资。 有的专业教师资源本身就不足, 而且部分教师尚未认识到 创新创业教育的重要性, 相当一部分没有真正意义上做过 


\section{3. 创新创业课程体系建设} 因此在创新创业方面没有体会, 难以胜任 “双创教育” 。 因此, 如何将 “双创教育” 有机地融入专业人才培养的全 过程, 是当前高等教育深化改革的重要课题。本文以闽江 学院物流工程专业为例, 通过剖析 “双创教育” 理念, 从 专业人才培养全过程的视角, 提出符合与创新教育理念相 适应的专业人才培养模式, 将 “双创教育” 有机地融入专 业人才培养的全过程。

\section{2. 学校顶层设计}

创新创业教育是提高高等教育质量的重要抓手, 创新创业 教育改革经历了一个不断深化的过程, 从 “大学生创新 实验项目”到“大学生创新创业训练计划项目”, 以及 2015 年开始的中国 “互联网+” 大学生创新创业大赛等, 均体 现了高等教育以创新创业人才培养为重点, 促进高等教育 与社会经济发展紧密结合。

创新创业教育的目标是培养具有创新精神和实践能力的 应用型人才。高校创新创业教育是一种全新的教育思想, 需要从人才培养定位、专业培养方案设计、课程体系重构、 实践教学改革、教学方法和教学内容革新、教育评价方式 变革等一系列环节进行改革, 因此创新创业教育需要从学 校的顶层设计开始, 谋划推进实施创新创业教育改革的具 体措施。

首先, 全校师生对创新创业教育的内涵的再认识。高校创 新创业教育改革的目的是要培养具有创新精神和实践能 力的应用型人才, 如果只是简单地开设几门创新创业的通 识课程或开设几节创新创业讲座, 绝非是创新创业教育的 初衷。早在 1989 年, 联合国教科文组织提出创新创业教 育需将事业心和开拓技能教育提高到与目前专业教育同 等地位 [4], 表明创新创业教育与专业教育同样重要, 不能 孤立, 必须将创新创业教育融入专业教育的全过程。

其次, 学校统筹规划创新创业教育改革, 建立创新创业学 院。闽江学院是首批福建省深化创新创业教育改革示范高 校。学校于 2017 年 4 月 7 日成立创新创业学院, 通过整 合各个系院及相关企业优质资源, 加强统筹规划, 推动学 校创新创业教育改革, 提升应用型人才培养质量。创新创 业学院遵循 “集聚资源、综合改革” 的总体思路, 以及 “为

“高水平有特色的应用型大学” 发展战略全局助力” 的定 位, 以福建省首家 “第二课堂成绩单” 改革试点高校建设 为契机, 量化学生创新创业能力的考核标准, 出台创新创 业教育的相关制度和激励措施, 有效地推动专业教育与创 新创业教育深度融合的改革局面。

最后, 学校层面需有完善的保障机制。学校引导和监督创 新创业教育, 将创新创业教育融入专业人才培养体系, 实 现理论与实践紧密结合, 增强学生的创新精神和创业意识。 学校要加强创新创业政策体系建设, 营造良好的创新创业 环境。搭建高校创建创业教育实践的平台, 保障学生通过 大学科技园区、创业园区、创业实验室或创业捊化器等创 业平台来帮助实现创业教育。构建完善的创新创业教育评 价与反馈机制, 不断深化创新创业教育改革, 逐步将创新 创业教育融入专业人才培养的全过程。
高校创新创业教育最直接的体现是专业人才培养方案, 在 培养方案中应明确以创新创业人才为导向的培养目标。在 此基础向, 构建合理的课程体系, 增加创新创业类的基础 课程, 强化专业课程的创新精神和实践能力的培养环节, 将创新创业教育融入专业教育的全过程 [5-7]。我国物流工 程本科专业最早设立于 2002 年, 由于起步较晚, 各个高 校的专业人才培养方案都处于探索和改进阶段, 学多学者 对物流工程专业的课程体系建设进行了研究 [8,9]。各高校 也根据各自的办学实际出发, 形成了各具特色的物流工程 专业课程体系, 但很少把创新创业教育完全融入专业人才 培养方案。

闽江学院顺应高等教育创新创业改革的大势, 在学校指导 性原则下, 对物流工程专业的课程体系进行重构。主要体 现在三个方面: 1）将创新创业教育理念融入理论课程; 强化实践教学课程, 重视开设跨专业课程; 重视学生第二 课堂教育, 将学科竞赛、创新创业项目、课外学术活动纳 入专业人才培养方案。

\section{1. 创新创业教育理念融入理论课程}

由于我国创新创业教育起步较晚, 许多学校从开设几门创 新创业通识课程开始, 逐步将创新创业教育理念融入专业 课程, 最终达到创新创业教育与专业教育的深度融合。在 不同年级开设通识课程、专业课程、跨专业平台课程等, 教师通过创新的教学内容、教学方法和考核方式, 将创新 创业教育理念融入课程的实施过程。通识课程主要传授创 新理念、创新思维、创新方法和创业意识等, 培养学生创 新创业思维, 激发学生的创新意识。专业课程侧重培养学 生的创新创业能力, 结合所学专业知识, 利用创新创业思 维去分析和解决实际专业领域问题。跨学科平台课程着重 培养学生跨学科知识和应用多种方法、技术解决实际问题 的能力。通过四年不间断的创新创业教育, 潜移默化地推 进专业教育与创新创业教育的深度融合。

\section{2. 强化实践教学课程}

创新创业教育的目标是培养创新精神和实践能力, 而实践 能力的培养主要依靠实践教学环节。学生在创新创业基础 课程的基础上, 针对专业领域的实际问题, 从可行性分析、 方案设计、效果检验等过程, 均需反复实践检验。实践课 程分为不同的类别体现在专业人才培养的全过程,包括课 程实验、集中实践课、专业实习、课程（实训）设计、毕 业实习和毕业论文等。依托学校实验室、工程实训中心、 科研平台、创业捊化基地等, 向学生全面开放实验环境和 实践场所, 开设开放型实验项目和创新活动项目; 依托合 作的实训基地和相关企事业单位，开设课程实训、专业实 习、毕业实习等实践课程。重构的实践课程体系是培养学 生创新思维和创业兴趣的有力保障, 成为专业教育与创新 创业教育之间的融合桥梁。 
造性为主要目标的教学方式转变。必须不断更新教学内容, 强调学生的创新思维训练, 发挥学生的学习主动性。强调 理论与实践的联系, 大力推行案例教学法, 广泛运用计算 机模拟情境教学等。对于实践教学环节, 通过整合创新, 实现实践教学内容体系的整体优化, 确立以课程实验、集 中实践、专业实习、论文设计四个环节为重点, 以学科竞 赛、双创项目、科研活动等为辅助的多层次实践教学体系, 坚持实践教学四年不断线,把实践教学贯穿到本科阶段的 整个学习过程。不断更新和优化实践教学内容, 增加综合 性、设计性、和开放性实验内容, 确保学生在实验教学环 节中得到充分的基本技能和创新能力训练。加强毕业设计 (论文) 联系实践的科研训练, 要求选题紧密结合教师的 科研课题、生产实际、社会工作等。

\section{4. 实施与保障机制}

创新创业的实施涉及教师、学生、教学资源等因素, 要顺 利地推进学校拟定的创新创业教育改革进程, 必须制定相 关管理制度和保障机制, 从教育理念、课程体系、师资队 伍、激励机制、人才质量评价等方面, 谋划科学合理的保 障机制。

\section{1. 构建双创型师资队伍培养机制}

教师是课堂教学的主体, 教师的教育理念和实践能力直接 影响创新创业教育的效果。要保证教学质量, 学校必须培 养一种具有创新教育理念和创新精神, 具有社会实践经验 和实际动手能力的 “双创型|师资队伍。“双创型” 教师应 能发现教育教学中存在的问题, 善于把教学工作与课题研 究有机地结合在一起, 能运用现代信息技术手段提高教育 教学效率。因此需要根据教师的个人兴趣和专业特长, 形 成激励教师参与提高创新能力的各类科学研究活动, 开展 近距离接触社会生活的企业挂职锻炼, 参加扩宽国际视野 的访学进修活动等, 构建 “双创型” 师资队伍的长期培养 机制。

闽江学院出台了《双师双能型教师队伍建设行动计划》, 制定了十三五期间的建设目标, 使各专业双师双能型教师 比例不低于 $50 \%$, 对于省级应用型学科和专业群双师双 能型教师比例达 $70 \%$ 。各教学单位根据专业发展需要, 选 派教师到合作实践基地、企事业单位学习和挂职锻炼, 积 极引进具有行业和工程背景的双师双能型教师, 并给符合 双师双能型的教师提供 500 元/月的岗位津贴, 指导学生 参加的学科竞赛、创新创业项目等活动均给予一定的奖励, 相关成果也作为教师职称评聘的条件或重要依据, 形成了 双师双能型教师的长效培养机制, 保证创新创业教育改革 的顺利实施。

\section{2. 改革传统教学机制}

教学方法是制约学生创新能力发展的主要因素。传统的教 学是以教师为中心, 学生被动式学习, 而创新创业教育理 念下的教学需以学生为中心, 将学生从被动式学习转为主 动式学习。教学方式必须实现从传统的以教师为中心的知 识传授型向知识传授与创新、与实践相结合, 师生互动、 教学相长, 并以调动学生自主学习、激发学生求知欲和创

\section{3. 构建 “双创型” 人才质量评价标准}

创新创业教育旨在提高人才培养质量, 是否达到预期的培 养目标需要运用科学的质量评价方法, 并将评价结果反馈 给学校和全体师生, 实现持续改进的创新创业教育局面。 由于高等教育是一个复杂的系统工程, 影响教育质量的因 素众多, 需要综合考虑教学理念、教学内容、教学方法、 学分认定、教师水平、激励措施等, 以学生的职业成长为 中心进行综合评判[10-12]。

“双创型”人才培养是以培养学生的创新精神和创业意识 为重点的一个过程, 对其考核不仅要看结果, 更要重视其 过程。因此, 考核方式的改革要强化综合素质和创新能力 的考核。传统的考核以偏重于对知识记忆的考核内容和评 价标准转变为针对学生的能力、素质与创新因素进行检测, 考核内容要尽量具有综合性, 能充分激发学生的创新意识, 能激励学生不遗余力地去分析和解决实际问题; 在评价标 准上, 把创新因素作为最主要的评判指标。建立以开卷考 核、分散考核、过程考核等灵活多样的考核方式。同时将

“双创” 精神和能力纳入考核指标体系, 学生量化综合测 评考核应补充和完善 “双创” 能力的测评。通过学生网上 评学、教师同行评价、教学督导评价, 以及社会用人单位 评价等, 对创新创业教育效果进行多方位评价。学校教学 处和创新创业学院综合评价和反馈意见, 对人才培养方案、 课堂建设负责人提出改进意见和建议, 形成持续改进的创 新创业实施和评价机制。

\section{5. 结论}

“双创型” 人才培养是当今高校人才培养的重要方向, 改 变传统的人才培养模式首先应该从专业人才培养的改革 开始, 对人才培养方案、实践教学、第二课堂设置、人才 质量评价等进行全方面的改革, 将 “双创教育” 有机地融 入专业人才培养的全过程。本文从创新创业教育的本质出 发, 探讨了高校实施创新创业教育的关键, 以闽江学院物 流工程专业为例, 对学校顶层设计、人才培养方案重构和 实施与保障机制方面进行了分析, 指出了我校创新创业教 育的一些做法和经验, 为创新创业教育与专业教育相融合 提供有效路径。 


\section{致谢}

本文为闽江学院创新创业教育教学改革研究项目《“双创 教育” 融入专业人才培养的改革与实践》(编号: 20181039504)的阶段性成果之一。

\section{参考文献}

[1] 秦波. 新时代视域下大学生创新创业教育的路径研究 [J]. 西南师范大学学报 (自然科学版) , 2018, 43(8): 143147.

[2] 陈春晓. 地方高校创业教育师资队伍建设的困境与机 制创新. 高等工程教育研究, 2017, (3):170-173.

[3] 翼宏, 顾永安, 张根华, 潘启勇, 费志勇. 应用型人才 培养视域下的创新创业教育探索 [J]. 江苏高教, 2016, (4): $77-80$.

[4] 吴伯志, 唐漟, 欧颖. 高校创新创业教育再认识. 国 家教育行政学院学报, 2017, (10):20-24.

[5] 仇存进. 我国高校创新创业教育课程体系研究. 江苏 高教, 2018, (11):82-85.

[6] 江帆, 张春良, 萧仲敏, 刘镇章. 机械专业创新创业 教育的构建. 高等工程教育研究, 2018, (6):168-172.

[7] 吴亚丽. 创新创业模式下专业基础课程教学改革初探. 教育理论与实践, 2017, 37(36):52-53.

[8] 徐天亮. 本科物流类专业设置体系与培养分工. 高等 工程教育研究, 2002,(2):23-25.

[9] 王忠伟, 庞燕. 物流工程本科专业课程体系构建路径 研究. 中南林业科技大学学报(社会科学版), 2011,(3):146147).

[10] 李亚东, 朱伟文. 高校创新创业教育评价监测研究. 中国高教研究, 2019, (1):48-51.

[11] 刘卫东, 雷轶. 基于人才培养全过程的创新创业课 程体系建设研究. 国家教育行政学院学报, 2017, (8):8-14. [12] 刘强. 我国高校创新创业教育质量评价体系的构建 与实践. 南昌工程学院学报, 2016, 35(2):5-7. 